\title{
A Study on the Parameters Effecting Yarn Snarling Tendency
}

\author{
Hikmet Şehit, Hüseyin Kadoğlu \\ Ege University, Faculty of Engineering, Department of Textile Engineering, 35100 Bornova, Izmir, Turkey
}

Corresponding Author: Hikmet Şehit, hikmtsehit@gmail.com

\begin{abstract}
The yarn is subjected to many internal stresses due to the raw material and yarn spinning steps used. When the yarn is relieved of the stresses it is subjected to, the yarn reacts inversely to the rotation defined as yarn liveliness. Yarn liveliness, may cause the spirality problem especially in the structure of knitted fabrics. The aim of this study is to investigate the effect of yarn spinning system, yarn count and twist coefficient on the tendency of yarn snarling. In this study, yarns were produced using $100 \%$ cotton materials, in five different spinning systems, taking two different twist coefficients into consideration, and in two yarn counts. Yarn liveliness values of samples were measured by Kringel Factor Meter Test Apparatus. As the twist coefficient of the yarns increases and the yarn becomes thicker, the snarling tendency increases. However, the highest yarn liveliness values were seen in the compact spinning system.
\end{abstract}

\author{
ARTICLE HISTORY \\ Received: 05.07.2019 \\ Accepted: 18.12.2019
}

\section{KEYWORDS}

Yarn liveliness, snarling tendency, twist effect, yarn properties

\section{INTRODUCTION}

Every stage in yarn production creates tension on the yarn structure. The main reason for this stress is the twist $[1,2]$. Every twisted yarn is being subjected to a permanent torque force on them. As soon as the yarns are released from this torque force, they start to snarl on themselves. The term of yarn liveliness, also referred to as twist liveliness or yarn snarling can be explained by the deterioration of the internal balance of the yarn as a result of the torsional force. The important point here is that the bending rigidity is direct proportional to the twisting resistance. That is, the more twist is given to the yarn, the greater the force shown against the twist [2].

Except some extreme cases, the snarl of the yarn on itself causes some problems. Particularly on the bobbin transfer stage, it causes disruption such as breaking by yarn liveliness. In the weaving step, it causes problems during the weft thread stroke. Due to the yarn liveliness, it causes the yarns to be mixed during the weft yarn stroke. This, results in machine downtime and loss of efficiency. It also causes problems for knitted fabric structures, which directly affect the quality of the fabric such as spirality. In knitted fabric structures, the yarn liveliness creates loops that are bent to right or left with the " $\theta$ " angle. This is called spirality problem of knitted fabrics [3]. The liveliness created by the twist causes a tension-induced break of the yarn during the skein dyeing of the yarn [4].

It has been found in the studies conducted by many researchers that some parameters directly affect the formation of yarn liveliness. Lord concluded that, the lower the twist, the easier it will be to get rid of the internal tension caused by twisting. The diameter of the yarn here is an important parameter. Because of the decrease in diameter of the yarn, the forces applied on the edges will become tighter. Thus, with this pressure on the fibers, it will be difficult to get rid of the effect of twisting [5]. Araujo and Smith concluded that vacuum steaming reduced the tendency of the snarling. It was concluded that the yarn liveliness values decreased gradually with the increase in

To cite this article: Şehit H, Kadoğlu H. 2020. A study on the parameters effecting yarn snarling tendency. Tekstil ve Konfeksiyon, 30(1), $42-49$. 
the vacuuming period, but not completely eliminated [6]. Kadoğlu investigated the effect of twist coefficient and spinning system on yarn liveliness. Accordingly, it is stated that there is a direct correlation between twist coefficient and liveliness. Besides, the snarling tendency of the open end yarns was significantly lower than the ring spinning system [7]. Primentas designed the Prianic tester to examine the yarn liveliness. In addition, it is emphasized that the measuring apparatus significantly reduces the operating time compared to other methods [8]. Marmarali stated in her study that relationship between twist factor and spirality to be directly proportional between these two parameters. Therefore, with the increase of the twist factor, the yarn liveliness increases and this increases the spirality [9]. Üreyen in study of yarn liveliness, he stated that as the twist coefficient increased, the yarn liveliness increased however as yarn count decreased, the liveliness values decreased [3]. Çelik did not use the standard loading weight of the Kringel Factor Meter, which is a measuring instrument for yarn liveliness. Instead of this, loading weight for each yarn number is calculated by the formula (yarn tex) x $10 \mathrm{mg}$. Accordingly, results of long staple fiber spinning showed that, yarn liveliness increased as the twist coefficient increased, but number change was not statistically significant. The highest $\mathrm{Kr}$ values were found to be in the compact, ring and siro-spun system, respectively. Stapel fiber spinning results showed that, the highest $\mathrm{Kr}$ values were found in the compact system and the lowest $\mathrm{Kr}$ values were in the open end system. In addition, there is a direct correlation between the yarn count and twist coefficient and the liveliness values [2]. Çelik and Kadoğlu studied yarn liveliness tendency of staple yarns and the results demonstrated that raw material, spinning system, yarn count, twist coefficient and steam process significant on yarn liveliness properties [1]. Çelik et al. have found that the effects of yarn count, twist coefficient and raw material on the yarn liveliness of siro spun yarns are significant. According to this, the liveliness values of acrylic yarns were found higher than that of wool yarns. Furthermore, the liveliness values of siro spun yarns were lower than the ring yarns [10]. $\mathrm{Xu}$ et al. have designed a computer aided measuring instrument that can automatically measure yarn liveliness. The twist tester is a recommended objective test instrument to measure the number of yarn snarl turns with image analyse [11]. Şardağ and Özdemir observed that the effect of vacuum has a significant effect on the yarn liveliness and decreases the liveliness. It was determined that the lowest liveliness values occurred in viscose fibers and the highest snarling tendency in staple polyester yarns. Additionally, as the twist coefficient increased and the yarn become coarser, the liveliness values increased [12, 13]. Bilir and Şardağ investigated performance characteristics of the Tencel ${ }^{\circledR}$ and cotton blended yarns. As a result, it was found that the amount of Tencel ${ }^{\circledR}$ fiber in the yarn had no direct effect on the yarn liveliness [14].
In this study, $100 \%$ cotton raw material was used as roving and sliver. Ring, compact, siro, compact siro and rotor spinning systems were preferred as spinning systems. The yarns were produced in two different yarn counts and by using two different twist coefficients. In addition, the results were analysed statistically by variance analysis. Although thick yarns have been studied in previous articles, this study is interested in thin yarn count (30/1 and 40/1 Ne) liveliness properties. The main reason for this prefer is the high amount of energy in thick yarns that cause the yarn to snarl [15]. However, in this study it is examined that whether thin yarns have the same effect as thick yarns or not. In addition, the twist coefficients of 3.6 and 4.2 have been preferred and a new perspective has been introduced especially for the yarns used in the knitted fabric industry. The aim of this study is to examine the yarn liveliness in different spinning systems, especially investigation of liveliness characteristics of the compact siro yarn system contrast to the previous studies. In this way, 5 different yarn structures were examined, which is the originality of the study, in order to investigate the effect of thin yarn counts on the snarling tendency for these systems.

\section{MATERIAL AND METHOD}

The main purpose of the study is to examine the effect of spinning systems, yarn count and twist on the yarn liveliness. In this context, $100 \%$ combed cotton raw material was used as sliver $(0.1 \mathrm{Ne})$ for open-end spinning and as roving for other systems $(0.8 \mathrm{Ne})$. Pinter Merlin SPA 1803 was used for the production of ring and siro spun yarns. For siro spun system, double roving was fed into the machine and the apparatus to keep the roving at the same distance. Rieter K45 spinning machine was used for compact and compact siro spinning processes. In the production of compact siro spun, the machine's original siro spinning system was used. The Rieter R40 Open End spinning machine was used for OE-Rotor yarns. The machine parameters are given in Table 1. In order to examine the effect of the yarn count, 30/1 and 40/1 Ne were choosen. In addition, $\alpha_{\mathrm{e}}=3.6$ and $\alpha_{\mathrm{e}}=4.2$ twist coefficients were applied to investigate the effect of yarn twist coefficient.

On the Rieter R40 spinning machine $90000 \mathrm{rpm}$ rotor speed and $7750 \mathrm{rpm}$ opening roller speed were fixed for all yarn types, in order to be able to investigate the effects of twist coefficient and yarn count. 33 XT-BD type rotor with a diameter of $40 \mathrm{~mm}$ and a circumference of $104 \mathrm{~mm}$ was used. As opening roller, B174 DN type opening roller was chosen.

While ring, rotor and compact spinning systems can work with all examples, 40/1 Ne yarns couldn't produced for siro and compact siro systems. This is because the draft value to be applied is too high and not within the machine limits. 
Subsequently yarns were conditioned for 24 hours at $20^{\circ} \mathrm{C} \pm 2$ and $65 \pm 5 \% \mathrm{RH}$. Vacuum steam process was not applied to the samples and measurements were made on crude yarns.

In this study, Kringel Factor Meter yarn liveliness test apparatus, which is shown in Figure 1 was used. The platefront of this test apparatus is divided into 10 parts. These 10 parts are available in 5 sections, each containing 0.2 units (Figure 1). The movement of this system is provided by the three-stage control button located in the upper right corner of the device. The yarn is passed through the first clamp when the button is in the free position. After that the button is adjusted to compress the $1^{\text {st }}$ clamp and the yarn is compressed. After the yarn is placed in the test apparatus, weights of $450 \mathrm{mg}$ for each number are separated from the yarn holders on the underside of the plate and hung on the yarn. The yarn depending on the liveliness it has, it comes to a fixed position and the expression read on the plate gives the liveliness value of the yarn. This value is defined as the $\mathrm{Kr}$ (Kringel) value of the yarn. The higher the $\mathrm{Kr}$ value, the higher the liveliness value of the yarn [16].

The measurement results were statistically evaluated in 95\% confidence limits. Variance analysis (ANOVA) was used to examine the effect of the spinning method on all parameters. To deduce whether the parameters were significant or not, $\mathrm{p}$ values were examined. According to the homogeneity of variances, Duncan or Dunnett tests and $F$ values and $\alpha=0.05$ significance were evaluated. The $t$ test was applied to determine the effect of yarn number and twist coefficient on yarn properties.

Table 1. The machine parameters

\begin{tabular}{|c|c|c|c|c|c|}
\hline & & Ring & Compact & Siro Spun & Compact Siro \\
\hline \multicolumn{2}{|c|}{ Spindle speed (rpm) } & 12.000 & 12.000 & 12.000 & 12.000 \\
\hline \multicolumn{2}{|c|}{ Ring diameter (mm) } & 40 & 40 & 40 & 40 \\
\hline \multirow{2}{*}{$\begin{array}{l}\text { Traveller } \\
\text { number }\end{array}$} & $30 / 1 \mathrm{Ne}$ & $45(3 / 0)$ & $45(3 / 0)$ & $45(3 / 0)$ & $45(3 / 0)$ \\
\hline & $40 / 1 \mathrm{Ne}$ & $31,5(6 / 0)$ & $31,5(6 / 0)$ & $31,5(6 / 0)$ & $31,5(6 / 0)$ \\
\hline
\end{tabular}

Table 2. The quality tests for yarn samples

\begin{tabular}{lll}
\hline Yarn tests and standards & Measurement tool & Number of measurement \\
\hline $\begin{array}{l}\text { Yarn tenacity } \\
\text { (TS 245 EN ISO 2062) }\end{array}$ & Lloyd yarn tenacity tester & 5 yarn samples/10 tests for each cops/bobbins \\
$\begin{array}{l}\text { Yarn elongation at break } \\
\text { (TS 245 EN ISO 2062) }\end{array}$ & Lloyd yarn tenacity tester & 5 yarn samples/10 tests for each cops/bobbins \\
$\begin{array}{l}\text { Yarn twist test } \\
\text { (TS 247 EN ISO 2061) }\end{array}$ & Zweigle D315 tester & 5 yarn samples/10 tests for each cops/bobbins \\
$\begin{array}{l}\text { Yarn unevenness test } \\
\text { (ISO 16549) }\end{array}$ & USTER tester 5 & 5 yarn samples/1 tests for each bobbins(The \\
Yarn count & measurement length was 1000 m cops/bobbins) \\
(TS 244 EN 150 2060) & USTER tester 5 & 5 yarn samples/1 tests for each bobbins (The \\
Yarn liveliness test & Kringel factor meter yarn liveliness & 5 yarn samples/10 tests for each cops/bobbins \\
\hline
\end{tabular}
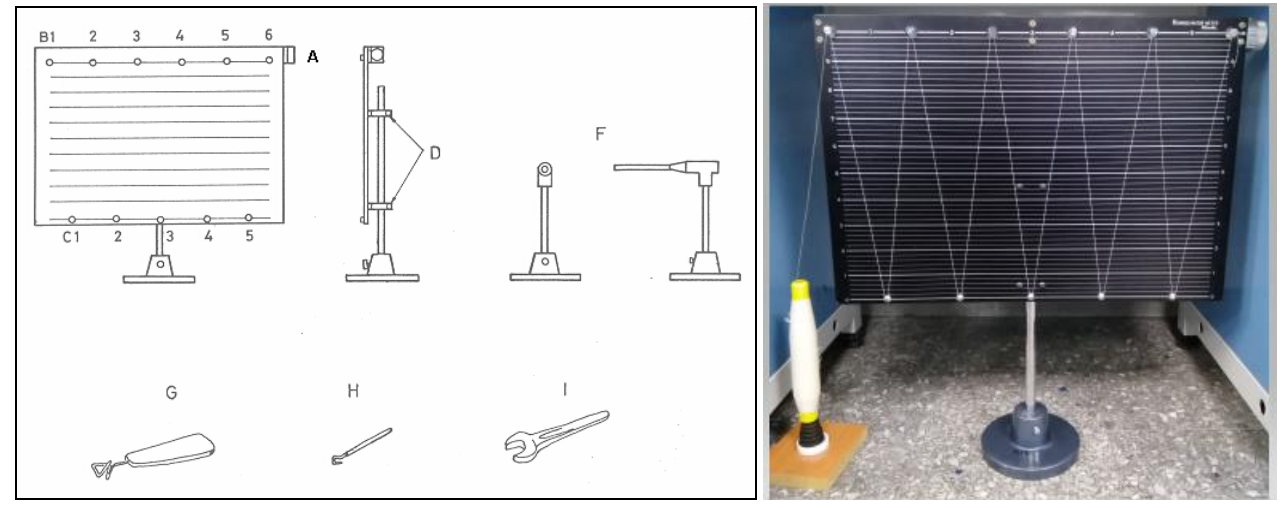

Figure 1. Kringel factor meter yarn liveliness test apparatus [15] 


\section{RESULTS AND DISCUSSION}

In this part yarn count, yarn tenacity, yarn breaking elongation, Uster unevennesses, twist values and yarn liveliness tests results were given in (Table 3-6).

\subsection{Influence of twist coeffifient on yarn liveliness}

The effect of the twist coefficient on yarn liveliness was found statistically significant (Figure 2, Figure 3 and Table 7). Considering the same spinning system and yarn count, it was seen that as the twist coefficient increases the values of liveliness $(\mathrm{Kr})$ also increases.

Table 3. Properties of $40 / 1 \mathrm{Ne}$ yarn samples

\begin{tabular}{|c|c|c|c|c|c|c|}
\hline \multirow[b]{2}{*}{ Twist coefficient $\left(\alpha_{e}\right)$} & \multicolumn{2}{|c|}{ Ring } & \multicolumn{2}{|c|}{ Compact } & \multicolumn{2}{|c|}{ Open end } \\
\hline & 3.6 & 4.2 & 3.6 & 4.2 & 3.6 & 4.2 \\
\hline $\begin{array}{l}\text { Yarn count }(\mathrm{Ne}) \\
(\% \mathrm{CV})\end{array}$ & $\begin{array}{l}40.43 \\
(2.12)\end{array}$ & $\begin{array}{l}39.58 \\
(0.86)\end{array}$ & $\begin{array}{l}39.01 \\
(1.20)\end{array}$ & $\begin{array}{l}40.07 \\
(2.50)\end{array}$ & $\begin{array}{l}39.38 \\
(0.92)\end{array}$ & $\begin{array}{l}39.49 \\
(0.96)\end{array}$ \\
\hline Tenacity (cN/tex) & 11.7 & 11.89 & 15.26 & 15.64 & 10.21 & 10.97 \\
\hline$(\% \mathrm{CV})$ & $(7.81)$ & $(9.09)$ & $(6.6)$ & $(6.69)$ & $(4.59)$ & (4.19) \\
\hline Elongation at break (\%) & 7.39 & 6.93 & 9.06 & 8.95 & 8.41 & 8.02 \\
\hline$(\% \mathrm{CV})$ & $(8.8)$ & $(9.58)$ & $(3.63)$ & $(8.74)$ & (4.73) & $(8.19)$ \\
\hline Uster \% CV & 13.52 & 17.38 & 13.7 & 13.37 & 4.56 & 4.47 \\
\hline Thin places $/ \mathbf{k m}$ & 126.2 & 176 & 5.4 & 2.6 & 104 & 121 \\
\hline Thick places/km & 375 & 415 & 87.8 & 27.6 & 92 & 135.6 \\
\hline Neps/km & 240 & 209 & 73 & 51 & 18 & 24 \\
\hline Yarn hairness $(\mathrm{H})$ & 4.98 & 4.77 & 3.55 & 3.42 & 4.56 & 4.47 \\
\hline
\end{tabular}

Table 4. Properties of 30/1 Ne yarn samples

\begin{tabular}{|c|c|c|c|c|c|c|c|c|c|c|}
\hline \multirow[b]{2}{*}{ Twist coefficient $\left(\alpha_{e}\right)$} & \multicolumn{2}{|c|}{ Ring } & \multicolumn{2}{|c|}{ Compact } & \multicolumn{2}{|c|}{ Open end } & \multicolumn{2}{|c|}{ Siro } & \multicolumn{2}{|c|}{ Compact siro } \\
\hline & 3.6 & 4.2 & 3.6 & 4.2 & 3.6 & 4.2 & 3.6 & 4.2 & 3.6 & 4.2 \\
\hline Yarn count $(\mathrm{Ne})$ & 29.84 & 28.27 & 28.27 & 29.64 & 29.88 & 29.24 & 28.91 & 29.04 & 29.38 & 28.93 \\
\hline$(\% \mathrm{CV})$ & $(1.21)$ & $(1.96)$ & $(1.18)$ & $(4.23)$ & $(2.51)$ & $(1.55)$ & $(1.93)$ & (2.33) & $(0.85)$ & $(1.05)$ \\
\hline Tenacity (cN/tex) & 13.42 & 15.95 & 16.53 & 17.09 & 10.43 & 12.02 & 14.95 & 16.03 & 16.63 & 18.43 \\
\hline$(\% \mathrm{CV})$ & $(4.85)$ & $(4.39)$ & $(3.36)$ & $(5.17)$ & $(3.51)$ & $(2.76)$ & $(9.17)$ & $(2.40)$ & $(5.23)$ & $(5.59)$ \\
\hline Elongation at break(\%) & 8.68 & 9.09 & 9.65 & 10.2 & 8.49 & 9.57 & 9.44 & 10.12 & 9.4 & 9.96 \\
\hline$(\% \mathrm{CV})$ & $(6.38)$ & $(2.62)$ & $(3.23)$ & $(3.14)$ & $(4.45)$ & $(2.98)$ & $(4.07)$ & $(4.17)$ & $(4.27)$ & (3.35) \\
\hline Uster \% CV & 14.03 & 14.35 & 11.22 & 12.18 & 11.44 & 12.59 & 14.1 & 15.42 & 13.32 & 14.26 \\
\hline Thin places/km & 8.2 & 11.2 & 3.4 & 1.2 & 59.8 & 70.4 & 17 & 79.60 & 5 & 11.6 \\
\hline Thick places/km & 89.6 & 116 & 26.8 & 13 & 11.4 & 62 & 74.4 & 108.2 & 94.9 & 146.8 \\
\hline Neps/km & 106.2 & 146.8 & 29 & 22.8 & 24.2 & 22 & 87.8 & 104.2 & 70.6 & 114.8 \\
\hline Yarn hairness (H) & 5.34 & 5.03 & 3.85 & 3.66 & 5.16 & 5.13 & 5.18 & 4.82 & 3.56 & 3.3 \\
\hline
\end{tabular}

Table 5. Twist values of yarn samples

\begin{tabular}{|c|c|c|c|c|c|}
\hline System & Yarn count $(\mathrm{Ne})$ & Twist coefficient $\left(\alpha_{e}\right)$ & T/m (theoric) & T/m (measured) & $\mathrm{T} / \mathrm{m}(\% \mathrm{CV})$ \\
\hline \multirow{4}{*}{ Ring } & $30 / 1$ & 3.6 & 776.88 & 825.04 & 2.48 \\
\hline & $30 / 1$ & 4.2 & 906.37 & 943.19 & 3.02 \\
\hline & $40 / 1$ & 3.6 & 897.07 & 933.97 & 2.97 \\
\hline & $40 / 1$ & 4.2 & 1046.58 & 1037.18 & 5.13 \\
\hline \multirow{4}{*}{ Open end } & $30 / 1$ & 3.6 & 776.88 & $776.88^{*}$ & - \\
\hline & $30 / 1$ & 4.2 & 906.37 & $906.37^{*}$ & - \\
\hline & $40 / 1$ & 3.6 & 897.07 & $897.07^{*}$ & - \\
\hline & $40 / 1$ & 4.2 & 1046.58 & $1046.58^{*}$ & - \\
\hline \multirow{4}{*}{ Compact } & $30 / 1$ & 3.6 & 776.88 & 840.73 & 3.67 \\
\hline & $30 / 1$ & 4.2 & 906.37 & 956.25 & 1.73 \\
\hline & $40 / 1$ & 3.6 & 897.07 & 962.53 & 3.54 \\
\hline & $40 / 1$ & 4.2 & 1046.58 & 1113.32 & 3.70 \\
\hline \multirow{2}{*}{ Siro } & $30 / 1$ & 3.6 & 776.88 & 804.21 & 2.86 \\
\hline & $30 / 1$ & 4.2 & 906.37 & 878.78 & 3.47 \\
\hline \multirow{2}{*}{ Compact siro } & $30 / 1$ & 3.6 & 776.88 & 758.37 & 3.13 \\
\hline & $30 / 1$ & 4.2 & 906.37 & 849.79 & 3.78 \\
\hline
\end{tabular}

* The theoric number of twists for open-end rotor yarns are taken. 
Table 6. Yarn liveliness values of all samples

\begin{tabular}{|c|c|c|c|c|c|}
\hline \multirow[b]{2}{*}{ Twist coefficient $\left(\alpha_{e}\right)$} & & \multicolumn{2}{|c|}{$30 / 1 \mathrm{Ne}$} & \multicolumn{2}{|c|}{$40 / 1 \mathrm{Ne}$} \\
\hline & & 3.6 & 4.2 & 3.6 & 4.2 \\
\hline \multirow{2}{*}{ Ring } & $\mathrm{Kr}$ & 4.44 & 4.88 & 4.25 & 4.66 \\
\hline & $\% \mathrm{CV}$ & 1.82 & 1.76 & 2.17 & 2.16 \\
\hline \multirow{2}{*}{ Compact } & $\mathrm{Kr}$ & 4.69 & 4.91 & 4.52 & 4.80 \\
\hline & $\% \mathrm{CV}$ & 1.13 & 3.09 & 1.28 & 1.17 \\
\hline \multirow{2}{*}{ Open-end } & $\mathrm{Kr}$ & 2.80 & 3.17 & 2.26 & 3.00 \\
\hline & $\% \mathrm{CV}$ & 2.55 & 3.11 & 3.92 & 4.04 \\
\hline \multirow{2}{*}{ Siro } & $\mathrm{Kr}$ & 4.36 & 4.72 & - & - \\
\hline & $\% \mathrm{CV}$ & 1.07 & 1.11 & - & - \\
\hline \multirow{2}{*}{ Compact siro } & $\mathrm{Kr}$ & 4.16 & 4.62 & - & - \\
\hline & $\% \mathrm{CV}$ & 2.1 & 1.1 & - & - \\
\hline
\end{tabular}

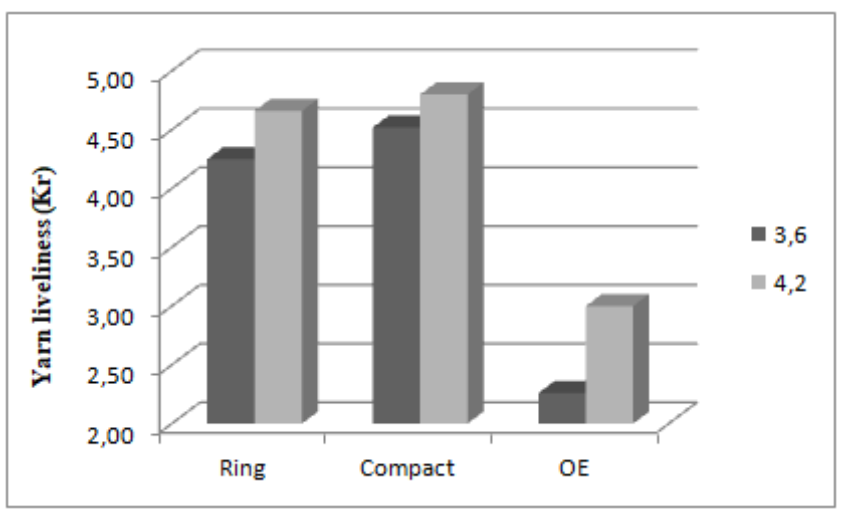

Figure 2. Influence of twist coefficient on 40/1 Ne samples

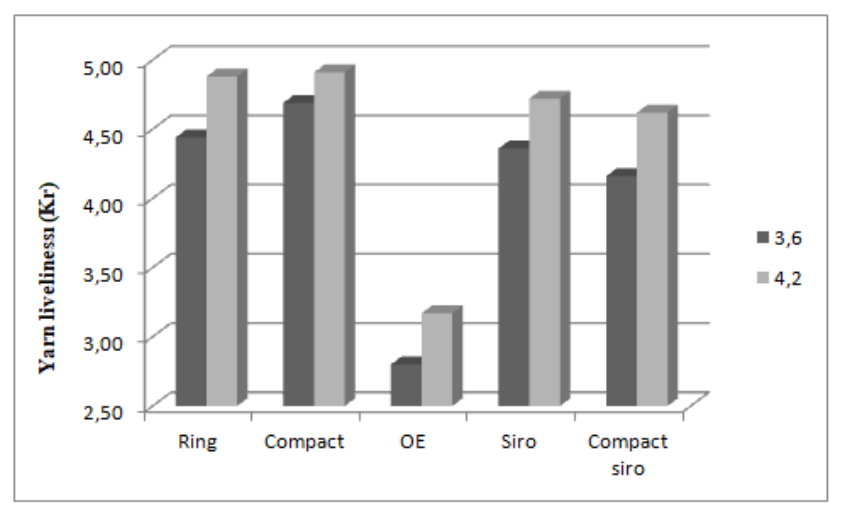

Figure 3. Influence of twist coefficient on 30/1 Ne samples

Table 7. The results of statistical analyses

\begin{tabular}{llll}
\hline Factor & Dependent variable $=$ Kr value & F & Significance* \\
\hline & 30/1 Ne Ring & 4.693 & $0.000^{*}$ \\
& 30/1 Ne Open end & 0.000 & $0.000^{*}$ \\
30/1 Ne Compact & 6.171 & $0.000^{*}$ \\
Twist coefficient & 30/1 Ne Siro & 0.297 & $0.000^{*}$ \\
& 30/1 Ne Compact siro & 16.613 & $0.000^{*}$ \\
& 40/1 Ne Ring & 16.287 & $0.000^{*}$ \\
40/1 Ne Open end & 1.641 & $0.000^{*}$ \\
40/1 Ne Compact & 0.969 & $0.000^{*}$ \\
\hline * Significant for $\alpha=0.05$ level. & &
\end{tabular}

* Significant for $\alpha=0.05$ level.

Although high twist strength increases, the yarn is caused to be rotated in the opposite direction. This can be explained by the reaction of the yarn in order to elimination the torsion strain that it is subjected to during twisting step. Hence, the higher twist coefficient, get greater the tendency of the yarn to snarling. This is consistent with the results of previous studies of Primentas; Çelik; Kadoğlu and Üreyen.

\subsection{Influence of yarn count on yarn liveliness}

Statistical analysis of data showed that different yarn counts create different twist liveliness values of long staple yarns for $\alpha=0.05$ (Figure 4 and Table 8).

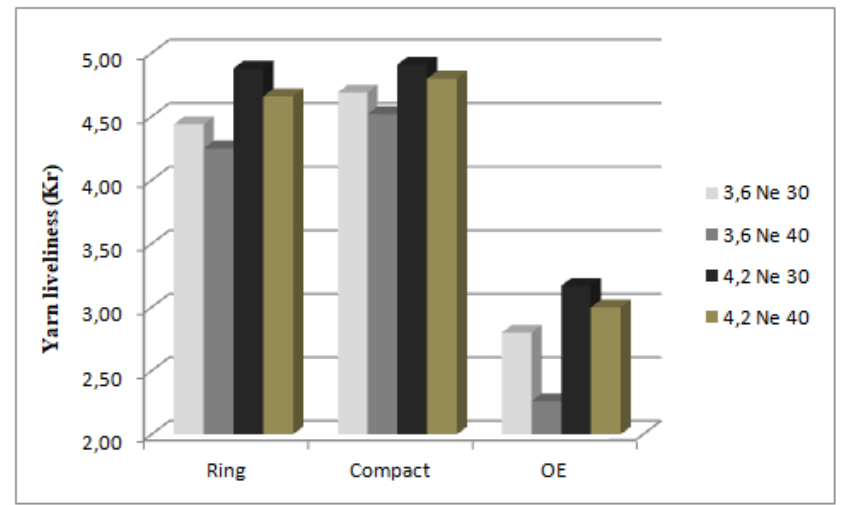

Figure 4. Influence of yarn count on yarn liveliness 
Table 8. The results of statistical analyses

\begin{tabular}{llll}
\hline Factor & Dependent variable $=$ Kr value & F & Significance* \\
\hline & $\alpha_{\mathrm{e}}=3.6$. Ring & 9.624 & $0.000^{*}$ \\
& $\alpha_{\mathrm{e}}=4.2$. Ring & 10.034 & $0.000^{*}$ \\
& $\alpha_{\mathrm{e}}=3.6$. Open end & 0.042 & $0.000^{*}$ \\
& $\alpha_{\mathrm{e}}=4.2$. Open end & 1.138 & $0.000^{*}$ \\
& $\alpha_{\mathrm{e}}=3.6$. Compact & 0.281 & $0.000^{*}$ \\
& $\alpha_{\mathrm{e}}=4.2$. Compact & 13.956 & $0.001^{*}$ \\
\hline
\end{tabular}

* Significant for $\alpha=0.05$ level.

Accordingly, the value of $\mathrm{Kr}$ increases as the yarn becomes coarser. This is explained by the accumulation of more energy in yarns. A coarse yarn count gets more amount of energy than a fine yarn count on a unit length of yarn, hence drawing forth a higher yarn liveliness value as well. As the energy accumulated on the yarn increases, the tendency to snarl will be higher. This is consistent with the results of previous study of Üreyen.

\subsection{Influence of spinning system on yarn liveliness}

When the results of the spinning system were analyzed (Figure 5, Table 9-13) the effect of the spinning system on the yarn liveliness was found statistically significant.

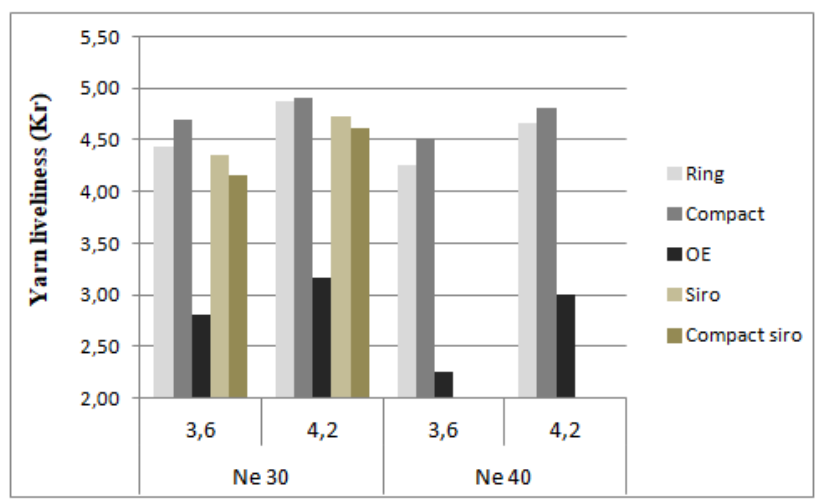

Figure 5. Influence of yarn count on yarn liveliness

Table 9. The results of statistical analyses

\begin{tabular}{llll}
\hline Factor & Dependent variable $=$ Kr value & F & \\
\hline & $30 / 1$ Ne. $\alpha_{\mathrm{e}}=3.6$ & 1162.333 & \\
Spinning system & $30 / 1$ Ne. $\alpha_{\mathrm{e}}=4.2$ & 1106.974 & $0.000^{*}$ \\
& $40 / 1$ Ne. $\alpha_{\mathrm{e}}=3.6$ & 3762.285 & $0.000^{*}$ \\
& $40 / 1$ Ne. $\alpha_{\mathrm{e}}=4.2$ & 2958.273 & $0.000^{*}$ \\
\hline$*$ Significant for $\alpha=0.05$ level & & & $0.000^{*}$ \\
\hline
\end{tabular}

* Significant for $\alpha=0.05$ level.

Table 10. Yarn liveliness values of $30 / 1 \mathrm{Ne}, \alpha_{\mathrm{e}}=3,6$ samples Duncan test

\begin{tabular}{|c|c|c|c|c|c|c|}
\hline \multirow{2}{*}{ Spinning systems } & \multirow{2}{*}{ Measurements } & \multicolumn{5}{|c|}{$\alpha_{\mathrm{e}}=3,6$} \\
\hline & & 1 & 2 & 3 & 4 & 5 \\
\hline Open end & 250 & 2,8008 & & & & \\
\hline Compact siro & 250 & & 4,1592 & & & \\
\hline Siro & 250 & & & 4,3628 & & \\
\hline Ring & 250 & & & & 4,4396 & \\
\hline Compact & 250 & & & & & 4,6880 \\
\hline Significance & & 1,000 & 1,000 & 1,000 & 1,000 & 1,000 \\
\hline
\end{tabular}

Table 11. Yarn liveliness values of $30 / 1 \mathrm{Ne}, \alpha_{e}=4,2$ samples Duncan test

\begin{tabular}{|c|c|c|c|c|c|}
\hline \multirow{2}{*}{ Spinning systems } & \multirow{2}{*}{ Measurements } & \multicolumn{4}{|c|}{$\alpha_{e}=4,2$} \\
\hline & & 1 & 2 & 3 & 4 \\
\hline Open end & 250 & 3,1668 & & & \\
\hline Compact siro & 250 & & 4,6224 & & \\
\hline Siro & 250 & & & 4,6996 & \\
\hline Ring & 250 & & & & 4,8828 \\
\hline Compact & 250 & & & & 4,9140 \\
\hline Significance & & 1,000 & 1,000 & 1,000 & 0,316 \\
\hline
\end{tabular}


Table 12. Yarn liveliness values of $40 / 1 \mathrm{Ne}, \alpha_{\mathrm{e}}=3.6$ samples Duncan test

\begin{tabular}{lllll}
\hline \multirow{2}{*}{ Spinning systems } & Measurements & \multicolumn{2}{c}{$\boldsymbol{\alpha}_{\mathbf{e}}=\mathbf{3 , 6}$} & $\mathbf{3}$ \\
\cline { 3 - 5 } & & $\mathbf{1}$ & $\mathbf{2}$ & \\
\hline Open end & 250 & 2,2560 & 4,2476 & 4,5180 \\
Ring & 250 & & & 1,000 \\
\hline Compact & 250 & 1,000 & 1,000 & \\
\hline Significance & & & & \\
\hline
\end{tabular}

Table 13. Yarn liveliness values of $40 / 1 \mathrm{Ne}, \alpha_{e}=4.2$ samples Duncan test

\begin{tabular}{lcccc}
\hline \multirow{2}{*}{ Spinning systems } & Measurements & \multicolumn{1}{c}{$\boldsymbol{\alpha}_{\mathrm{e}}=\mathbf{4 . 2}$} & $\mathbf{2}$ & $\mathbf{3}$ \\
\cline { 3 - 5 } & 250 & 3.0024 & & \\
\hline Open end & 250 & & 4.6588 & \\
Ring & 250 & & & 4.7900 \\
Compact & & 1.000 & 1.000 & 1.000 \\
\hline Significance & & &
\end{tabular}

It is seen that the lowest liveliness values for 30/1 Ne yarn samples exist in the open end system, followed by compact siro, siro, ring systems and the highest values in the compact spinning system. Similarly, on the 40/1 Ne yarns it was observed that the lowest snarling tendency was observed in rotor yarns and the highest values were in compact yarns. As it is known open-end yarns have certain fibre belts on yarn surface. Therefore, open-end yarns have the lowest liveliness. Siro and compact siro yarns are stable in comparison to ring and compact systems. Thus, the snarling tendency is not very high. In compact yarns, the settlement of the fibers in the yarn structure is higher. Due to the excess of fibers added to the yarn structure according to this system, the torsional force to be created by the fibers is higher than other yarns. So, the yarn liveliness values of compact yarns are higher. This is consistent with the results of previous study of Kadoğlu and Çelik.

\subsection{Influence of the other yarn parameters on yarn liveliness}

It has been observed that yarn liveliness increases with increasing yarn strength in some yarn types (Table 3-5). However, this increase was not found in all yarn types and was not statistically significant.

As a result, it is not possible to decide a relationship between tenacity and liveliness. On the other hand, it was not observed any significant relation between the hairiness and irregularity of yarns over the yarn liveliness characteristic.

\section{CONCLUSION}

The yarn acquires tension due to both twisting and spinning processes. It has the desire to get rid of this tension even when it is released as a yarn or fabric. In this study, the evaluated parameters are concentrated on the yarn twist coefficient, yarn count and spinning system. In the experimental part, the yarn liveliness was investigated with the Kringel Factor Meter Tester. The data obtained are evaluated and the results are stated below:

- The effect of twist coefficient on yarn liveliness was found significant. As the twist coefficient increases in the same yarn count and system, the snarling tendency of the yarn, i.e. the yarn liveliness values, increase. This result is in parallel with many studies. (Kadoğlu; Primentas; Üreyen; Çelik; Şardağ and Özdemir).

- If an association is made between the yarn liveliness and the yarn count, yarn count also has a significant effect on the yarn liveliness. According to these results, in the same twist coefficient 30/1 Ne yarn liveliness values were higher than $40 / 1 \mathrm{Ne}$ samples. As a result, it has been seen if the yarn becomes coarser the liveliness increases. The similar results were seen in the study conducted by Üreyen.

- On the other hand, the effect of spinning system on yarn liveliness is also significant. The liveliness values of the 30/1 Ne samples can be ranked as compact, ring, siro, compact siro and open end rotor, respectively. Similarly, yarn liveliness values of 40/1 Ne samples were found compact, ring, open end rotor, respectevly. All these results were compared to the other studies by Kadoğlu; Çelik. This result is consistent with many other studies. 


\section{REFERENCES}

1. Çelik P, Kadoğlu H. 2009. A research on yarn liveliness tendency of staple yarns. Tekstil ve Konfeksiyon 19(3), 189-196.

2. Çelik P. 2006. Kesikli lif ipliklerinde kendi üzerine kıvrılma eğilimi (iplik canlılığı) ve bunu etkileyen faktörler üzerine bir araştırma (Doctoral dissertation). Ege University Graduate School of Natural and App. Science Textile Engineering Department, Izmir.

3. Üreyen ME. 2005. Pamuk ring ipliklerinde iplik canlılığı ile lif özellikleri ve bazı iplik özellikleri arasındaki ilişkiler. Tekstil ve Konfeksiyon 15(1), 12-18.

4. Murrels CM, Tao XM, Cheng KPS, Wang KK. 2003. Production of torque-free single ring yarns. Textile Asia August, 58-60.

5. Lord PR. 1981. The economics, science and technology of yarn production. Cambridge: Woodhead Publishing Ltd.

6. Araujo M, Smith G. 1989. Spirality of knitted fabrics Part-I: The nature of spirality. Textile Research Journal 59(6), 247-256.

7. Kadoğlu H. 2000. Pamuk ipliklerinde kendi üzerine kıvrılma eğilimi (iplik canlılığı) üzerine bir araştırma. Tekstil Türkiye Kasım, 26-31.

8. Primentas A. 2003. Direct determination of yarn snarlines. Indian Journals of Fibre \& Textile Research 28(1), 23-28.

9. Marmaralı A. 2005. Tek ve çift katlı ipliklerin büküm katsayılarının düz örgü yapılarındaki örgü dönmesine etkisi. Tekstil ve Konfeksiyon 15(1), 8-11.
10. Çelik P, Bedez ÜT, Kadoğlu H. 2010, May. The yarn liveliness properties of sirospun yarns. Proceedings of the $41^{\text {st }}$ International Symposium on Novelties in Textiles, Ljubliana, Slovenia.

11. Xu BG, Tao XM, Murrels CM. 2010. Evaluation of a digital imagesignal approach on the automatic measurement of cotton yarn snarls. Textile Research Journal 80(12), 1151-1159.

12. Şardağ S, Özdemir Ö. 2013. Effects of vacuum steaming process on the twist liveliness of staple yarns. Fibre \& Textiles in Eastern Europe 5(101), 49-53.

13. Özdemir Ö, Kanık M, Şardağ S. 2007. Vakumlu buharlama işlemlerinin iplik özelliklerine etkisinin araştırılması (Project No: 105M333). Place: TÜBİTAK.

14. Bilir TB, Şardağ S. 2017. Tencel ve pamuk karıșımlı ipliklerin performans özelliklerinin incelenmesi. Uludağ Üniversitesi Mühendislik Fakültesi Dergisi 22(1), 13-27.

15. Sehit H, Kadoğlu H. 2019, Eylül. İpliğin dönme eğilimini etkileyen parametreler. Ulusal Çukurova Tekstil Kongresi UÇTEK (33-40). Adana, Türkiye.

16. Kringel Factor Meter Instruction Manuel Book. Keisokki Kogyo Co. Ltd.

17. Şehit H. 2018. İplik canlılığının (kendi üzerine kıvrılması) araştırılması ve örme kumaşlarda may dönmesi üzerine etkisi (Master's thesis). Ege University Graduate School of Natural and App. Science Textile Engineering Department, Izmir. 